\title{
Consumption of light foods and drinks among adults
}

\author{
Konsumpcja produktów typu light wśród osób dorosłych \\ Elżbieta Szczepańska (D), Elwira Grudowska \\ Department of Human Nutrition, Faculty of Health Sciences in Bytom, Medical University of Silesia, Katowice, Poland
}

\begin{abstract}
INTRODUCTION: Nutritional habits are significant not only in maintaining good health, but also in preventing many diseases. Proper nutrition also helps to maintain the right body weight. Due to growing consumer interest in these issues, a new food market sector, namely light foods, has emerged. The aim of the study was to assess the consumption frequency of light foods and drinks and to analyse the relationship between the consumption frequency and age, education and body weight of the respondents.

MATERIAL AND METHODS: The study involved 203 adults who declared the consumption of light foods and drinks. The frequency of consuming light foods and drinks was assessed on the basis of the author's own survey questionnaire. RESULTS: The largest proportion of respondents choose light dairy products several times a week (23.2\%) or occasionally (40.4\% of respondents). Fat products of a light type and light sweets were consumed occasionally by $34.5 \%$ and $30 \%$ of respondents respectively. Light drinks were in most cases consumed several times a month (20.7\%) and occasionally $(40.4 \%)$.

CONCLUSIONS: The consumption of fast foods is rare among the respondents. There was a weak or low correlation between the frequency of light food consumption and age, education and body weight of the respondents. It seems necessary to provide nutrition education from an early age, especially among children and adolescents, and to continue it with adults.
\end{abstract}

\section{KEY WORDS}

health, nutrition, light foods and drinks

\section{STRESZCZENIE}

WSTĘP: Sposób żywienia ma znaczenie nie tylko dla utrzymania dobrego stanu zdrowia, ale również w prewencji wielu chorób. Prawidłowe odżywianie pozwala także utrzymać właściwą masę ciała. Z powodu zwiększenia zainteresowania konsumentów tymi zagadnieniami zaczął rozwijać się nowy sektor rynku żywnościowego, tj. produkty typu light. Celem pracy była ocena częstości ich spożycia oraz analiza zależności pomiędzy częstością konsumpcji a wiekiem, wykształceniem i masą ciała badanych osób.

MATERIAŁ I METODY: W badaniu brały udział 203 dorosłe osoby, które deklarowały spożywanie produktów typu light. Częstotliwość ich konsumpcji oceniano na podstawie autorskiego kwestionariusza ankiety.

Address for correspondence: Dr n. med. Elżbieta Szczepańska, Zakład Żywienia Człowieka, Katedra Dietetyki, Wydział Nauk o Zdrowiu w Bytomiu, Śląski Uniwersytet Medyczny w Katowicach, ul. Jordana 19, 41-808 Zabrze, tel. +48 3227551 97, e-mail: eszczepanska@sum.edu.pl 
WYNIKI: Największy odsetek badanych sięga po produkty mleczne typu light kilka razy w tygodniu (23,2\%) lub okazjonalnie (40,4\% badanych). Produkty thuszczowe i słodycze typu light były spożywane okazjonalnie przez odpowiednio $34,5 \%$ i $30 \%$ badanych osób. Napoje typu light w większości przypadków były konsumowane kilka razy w miesiącu $(20,7 \%)$ i okazjonalnie $(40,4 \%)$.

WNIOSKI: Wśród ankietowanych osób spożycie żywności typu fast food jest rzadkie. Stwierdzono występowanie słabej lub niskiej korelacji pomiędzy częstością spożycia żywności typu light a wiekiem, wykształceniem i masą ciała badanych osób. Konieczne wydaje się prowadzenie edukacji żywieniowej od najmłodszych lat, szczególnie wśród dzieci i młodzieży oraz jej kontynuowanie w populacji osób dorosłych.

\section{SŁOWA KLUCZOWE}

zdrowie, odżywianie, produkty light

\section{INTRODUCTION}

Among a growing group of consumers, there is rising interest in taking care of one's health and slowing down or inhibiting ageing processes [1]. Many research results indicate that nutritional habits are of great importance not only to maintain good health but also to prevent many diseases. Proper nutrition also helps to maintain the right body weight [2]. Due to growing consumer interest in these issues, a new food market sector, referred to as functional food, began to emerge. Such food may be produced by adding biologically active compounds, by removing the anti-nutrient components, by lowering the content of individual components or using substitutes for undesirable substances (e.g. low energy density foods with reduced salt, sugar or cholesterol) $[3,4]$. For this type of food, its definition, functions and intended use are known and described in regulations that govern the issues related to it [5]. Concurrently, another group of food products has emerged - light foods and drinks, which are often alternately described by manufacturers as light, fit, figure, slim, fitness, $0 \%$ fat, and by their name suggesting that they are low energy density foods and are often identified with them. However, the actual energy content of these products may be entirely different than expected. When selecting a food product and assessing its nutritional value, not only the energy value but also the content of individual nutrients should be taken into account. The composition of the product should also be analysed for the content of additives or substitutes for substances naturally present in it, which not only have no nutritional value, but are often suspected of having adverse effects and having a negative impact on health [6]. These are the reasons that should determine the choice of food products and the frequency of their consumption.

\section{AIM OF THE STUDY}

The main aim of the study was to assess the consumption frequency of light foods and drinks among adults. The specific aims concerned:

1) analysing the consumption frequency taking into account age, education and body weight;

2) identifying the motive to select light foods and drinks.

\section{WSTĘP}

Wśród coraz liczniejszej grupy konsumentów wzrasta zainteresowanie dbałością o zdrowie oraz spowolnieniem lub zahamowaniem procesów starzenia się organizmu [1]. Liczne wyniki badań potwierdzają, iż sposób żywienia ma ogromne znaczenie nie tylko dla utrzymania dobrego stanu zdrowia czy utrzymania właściwej masy ciała, lecz także w prewencji wielu chorób. [2]. $\mathrm{Z}$ powodu coraz większego zainteresowania konsumentów tymi zagadnieniami zaczął rozwijać się nowy sektor rynku żywnościowego, zwanego żywnością funkcjonalną. Może być wytwarzana poprzez wzbogacenie jej składnikami aktywnymi biologicznie, usuwanie składników antyodżywczych czy obniżenie zawartości poszczególnych składników lub użycie zamienników substancji niepożądanych (np. żywność o obniżonej wartości energetycznej, z ograniczeniem soli, cukru czy cholesterolu) $[3,4]$. W przypadku tej żywności znane i opisane są: jej definicja, funkcje i przeznaczenie, a pozostałe kwestie z tym związane regulują odpowiednie rozporządzenia [5]. Jednocześnie powstała również grupa produktów spożywczych typu light, które często opisywane są przez producentów zamiennie jako lekkie, fit, figura, slim, fitness, $0 \%$ tłuszczu i przez swą nazwę sugerujące, że są produktami o obniżonej wartości energetycznej i nierzadko z takimi utożsamiane. Rzeczywista wartość energetyczna tych produktów może jednak być zupełnie inna od oczekiwanej. Wybierając produkt spożywczy i oceniając jego wartość odżywczą pod uwagę brać należy nie tylko wartość energetyczną, lecz także zawartość poszczególnych składników odżywczych. Skład produktu powinno się także analizować pod kątem zawartości w nim substancji dodatkowych lub zastępujących naturalne. Nie tylko bowiem nie posiadają one wartości odżywczej, ale często podejrzewane są o działania niepożądane i wywoływanie niekorzystnych skutków zdrowotnych [6]. To właśnie te przesłanki powinny stanowić o wyborze produktów spożywczych i częstości ich konsumpcji.

\section{CEL PRACY}

Celem głównym pracy była ocena częstości spożycia produktów typu light wśród osób dorosłych. Cele szczegółowe dotyczyły: 


\section{MATERIAL AND METHODS}

The study was conducted personally among 203 adults living in Gliwice, Bytom and Zabrze, declaring the consumption of light foods and drinks. The research tool was the author's own survey questionnaire containing 37 closed, single-choice questions. The first part of the questionnaire was the so-called demographics. The main part included questions relating to the consumption frequency of light foods and drinks (including those described by the producers as fit, figure, slim, fitness, $0 \%$ fat), from individual product groups (cereal, dairy, fat products, sweets, drinks) and the motive to select this type of products. To assess the frequency of consumption, there were the following answer choices: daily, several times a week, several times a month, rarely, I don't consume.

The obtained results were stored in MS Excel. The respondents were divided into two age groups: 19-30 years of age $(n=120)$ and over 30 years of age $(n=83)$; three levels of education were also identified: vocational $(n=32)$, secondary $(n=88)$, higher $(n=83)$, and three ranges of body weight assessed on the basis of BMI: underweight $(\mathrm{n}=18)$, normal body weight $(\mathrm{n}=115)$ and overweight $(n=70)$. Statistical analysis was performed using Statistica 10.0. Cramér's V, the gamma rank correlation coefficient and Spearman's rank correlation coefficient were used to assess the relationship. The following ranges were used to assess the strength of the correlation:

$-<0-0.2>-$ weak correlation

$-0.2-0.4>-$ law correlation

$-0.4-0.7>-$ moderate correlation

$-0.7-0.9>-$ strong correlation

$-0.9-1>-$ very strong correlation

The value of $p<0.05$ was considered statistically significant for all the analyses.

\section{RESULTS}

Among all the respondents, 59\% represented people from the 19-30 age group, the remaining $41 \%$ were over 30 years old. The highest number of people had secondary education (43\%), then higher education (41\%), while the lowest number of people had vocational education (16\%). $57 \%$ of all the respondents had normal body weight, $34 \%$ were overweight and $9 \%$ were underweight.

The consumption frequency of light foods and drinks from individual product groups by all the respondents, including age, education level and body weight according to BMI values are shown in Tables I-V.

The respondents most often reported rare consumption of light cereal products, including a higher percentage of people over 30 years of age than in the age group of 19-30, with vocational education rather than higher and secondary education, and overweight rather than with normal body weight. The underweight respondents
1) analizy częstości spożycia z uwzględnieniem wieku, wykształcenia i masy ciała oraz;

2) wskazania motywu wyboru produktów typu light.

\section{MATERIA I METODY}

Badania przeprowadzono osobiście wśród 203 dorosłych osób zamieszałych na terenie miast Gliwice, Bytom i Zabrze, deklarujących spożywanie produktów typu light. Narzędziem badawczym był autorski kwestionariusz ankiety zawierający 37 pytań zamkniętych jednokrotnego wyboru. Pierwszą część kwestionariusza stanowiła tzw. metryczka. W części właściwej znajdowały się pytania odnoszące się do częstości spożycia produktów typu light (w tym także opisywanych przez producentów jako produkty fit, figura, slim, fitness, $0 \%$ tłuszczu), z poszczególnych grup asortymentowych (produkty zbożowe, mleczne, tłuszczowe, słodycze, napoje) oraz motywu wyboru tego typu produktów. Do oceny częstości spożycia wyodrębniono następujące warianty odpowiedzi: codziennie, kilka razy w tygodniu, kilka razy w miesiącu, rzadko, nie spożywam.

Uzyskane wyniki zgromadzono w programie MS Excel. Badane osoby zostały podzielone na dwie grupy wiekowe: $19-30$ lat $(n=120)$ i powyżej 30 lat $(n=83)$; wyróżniono również trzy poziomy wykształcenia: zawodowe $(n=32)$, średnie $(n=88)$, wyższe $(n=83)$ oraz trzy zakresy masy ciała ocenianej na podstawie wskaźnika BMI: niedowaga $(\mathrm{n}=18)$, prawidłowa masa ciała $(n=115)$ oraz nadwaga $(n=70)$. Analizę statystyczną przeprowadzono za pomocą programu Statistica 10.0. Do oceny zależności wykorzystano: współczynnik zależności V-Cramera, współczynnik korelacji rang gamma oraz współczynnik korelacji rang Spearmana. Do oceny siły korelacji przyjęto następujące przedziały:

$-<0-0,2>-$ korelacja słaba

$-0,2-0,4>-$ korelacja niska

$-0,4-0,7>-$ korelacja umiarkowana

$-0,7-0,9>-$ korelacja silna

$-0,9-1>-$ korelacja bardzo silna

Dla wszystkich analiz za istotną statystycznie przyjęto wartość $\mathrm{p}<0,05$.

\section{WYNIKI}

Spośród wszystkich badanych 59\% stanowiły osoby z grupy wiekowej 19-30 lat, pozostałe 41\% to osoby powyżej 30 r.ż. Najwięcej osób legitymowało się wykształceniem średnim (43\%), dalej wykształceniem wyższym $(41 \%)$, natomiast najmniej wykształceniem zawodowym (16\%). 57\% spośród wszystkich uczestniczących w badaniu charakteryzowało się prawidłową masą ciała, 34\% nadwagą, a 9\% niedowagą.

Częstość spożycia produktów typu light z poszczególnych grup asortymentowych przez wszystkich badanych łącznie oraz z uwzględnieniem wieku, poziomu wykształcenia i masy ciała według wartości wskaźnika BMI przedstawiają tabele I-V. 
most often indicated that they consume these products several times a week (Tab. I).

Statistical analysis revealed a correlation $(\mathrm{p}<0.05)$ between the consumption frequency of light cereal products and:

- age $(\mathrm{r}=-0.17$; weak correlation $)$

- educational level $(r=-0.05$; weak correlation)

- body weight of respondents $(r=-0.3$; low correlation).

The respondents most often reported rare consumption of light dairy products, including a higher percentage of people over 30 years of age than in the age group of 19-30, with higher rather than vocational or secondary education and normal body weight rather than overweight. The underweight consumers equally often indicated that they consume these products rarely and several times a week (Tab. II).

Statistical analysis revealed a correlation $(\mathrm{p}<0.05)$ between the consumption frequency of light dairy products and:

- age $(\mathrm{r}=-0.04$; weak correlation $)$,

- educational level $(\mathrm{r}=-0.12$; weak correlation),

- body weight of respondents $(r=-0.04$; weak correlation).

The respondents most often declared that they do not consume light-type fat products, including a higher percentage of people over 30 years of age than in the 19-30 age group, with higher rather than vocational or secondary education and more often overweight than with normal body weight and underweight (Tab. III).

Statistical analysis revealed a correlation $(p<0.05)$ between the consumption frequency of light-type fat products and:

- age ( $r=-0.03$; weak correlation),

- educational level $(r=-0.21$; low correlation),

- body weight of respondents $(r=0.07$; weak correlation).

The respondents most often declared that they do not consume light sweets, including more respondents over 30 years of age than in the 19-30 age group, with higher rather than vocational or secondary education and with normal body weight rather than underweight and overweight (Tab. IV).

Statistical analysis revealed a correlation $(p<0.05)$ between the consumption frequency of light sweets and:

- age $(r=-0.13$; weak correlation $)$,

- educational level ( $r=-0.33$; low correlation),

- body weight of respondents $(r=0.04$; weak correlation).

The respondents most often indicated rare consumption of light drinks, including a higher percentage of people over 30 years of age than in the 19-30 age group, with higher rather than vocational or secondary education and overweight rather than with normal body weight and underweight. In the underweight group, the highest percentage was represented by respondents who do not consume light drinks (Tab. V).
Badani najczęściej wskazywali na rzadkie spożycie produktów zbożowych typu light, w tym większy odsetek osób powyżej 30 r.ż., w porównaniu z grupą 19-30 lat, z wykształceniem zawodowym w korelacji z wyższym i średnim oraz $\mathrm{z}$ nadwagą w porównaniu z prawidłową masa ciała. Konsumenci z niedowagą najczęściej spożywali te produkty kilka razy w tygodniu (tab. I).

Analiza statystyczna wskazała na występowanie korelacji $(\mathrm{p}<0,05)$ pomiędzy częstością spożycia produktów zbożowych typu light oraz:

- wiekiem ( $\mathrm{r}=-0,17$; korelacja słaba)

- poziomem wykształcenia $(r=-0,05$; korelacja słaba)

- masą ciała badanych konsumentów ( $\mathrm{r}=-0,3$; korelacja niska).

Badane osoby wskazywały na rzadkie spożycie produktów mlecznych typu light, w tym więcej osób powyżej 30 r.ż. niż w przedziale wiekowym 19-30 lat, z wykształceniem wyższym niż zawodowym lub średnim oraz z prawidłową masa ciała niż nadwagą. Konsumenci z niedowagą równie często jak pozostali wskazywali na spożywanie tych produktów rzadko oraz kilka razy w tygodniu (tab. II).

Analiza statystyczna wskazała na występowanie korelacji $(\mathrm{p}<0,05)$ pomiędzy częstością spożycia produktów mlecznych typu light oraz:

- wiekiem ( $r=-0,04$; korelacja słaba),

- poziomem wykształcenia $(\mathrm{r}=-0,12$; korelacja słaba),

- masą ciała badanych konsumentów ( $r=-0,04$; korelacja słaba).

Badani konsumenci najczęściej deklarowali, że nie spożywają produktów tłuszczowych typu light, w tym większy odsetek osób powyżej 30 r.ż. niż w przedziale wiekowym 19-30 lat, z wykształceniem wyższym niż zawodowym lub średnim oraz $\mathrm{z}$ nadwagą niż z prawidłową masą ciała i niedowagą (tab. III).

Analiza statystyczna wskazała na występowanie korelacji $(\mathrm{p}<0,05)$ pomiędzy częstością spożycia produktów tłuszczowych typu light oraz:

- wiekiem ( $r=-0,03$; korelacja słaba),

- poziomem wykształcenia $(\mathrm{r}=-0,21$; korelacja niska),

- masą ciała badanych konsumentów $(r=0,07$; korelacja słaba).

Badane osoby najczęściej deklarowały, że nie spożywają słodyczy typu light, w tym więcej badanych powyżej 30 r.ż. niż z grupy wiekowej 19-30 lat, z wykształceniem wyższym niż $\mathrm{z}$ zawodowym lub średnim oraz $\mathrm{z}$ prawidłową masą ciała niż $\mathrm{z}$ niedowagą i nadwagą (tab. IV).

Analiza statystyczna wskazała na występowanie korelacji $(\mathrm{p}<0,05)$ pomiędzy częstością spożycia słodyczy typu light oraz:

- wiekiem ( $\mathrm{r}=-0,13$; korelacja słaba),

- poziomem wykształcenia $(\mathrm{r}=-0,33$; korelacja niska),

- masą ciała badanych konsumentów $(r=0,04$; korelacja słaba).

Badane osoby najczęściej wskazywały na rzadkie spożycie napojów typu light, w tym większy odsetek osób 
Table I. Consumption frequency of light cereal products by age, education and body weight of respondents

Tabela I. Częstość spożycia produktów zbożowych typu light z uwzględnieniem wieku, wykształcenia i masy ciała badanych konsumentów

\begin{tabular}{|c|c|c|c|c|c|}
\hline \multirow{2}{*}{ Features/Cechy } & \multicolumn{5}{|c|}{$\begin{array}{l}\text { Consumption frequency of light cereal products indicated by respondents (\%)/ } \\
\text { Częstość spożycia produktów zbożowych typu light wskazana przez badanych (\%) }\end{array}$} \\
\hline & $\begin{array}{c}\text { daily/ } \\
\text { codziennie }\end{array}$ & $\begin{array}{l}\text { several times a week/ } \\
\text { kilka razy w tygodniu }\end{array}$ & $\begin{array}{l}\text { several times a month/ } \\
\text { kilka razy w miesiącu }\end{array}$ & $\begin{array}{l}\text { rarelyl } \\
\text { rzadko }\end{array}$ & $\begin{array}{l}\text { i don't consumel } \\
\text { nie spożywam }\end{array}$ \\
\hline \multicolumn{6}{|l|}{ Age/Wiek: } \\
\hline 19-30 years/lat & 9.2 & 25 & 20.8 & 38.3 & 6.7 \\
\hline$>30$ years/lat & 7.2 & 16.9 & 19.3 & 50.6 & 6.0 \\
\hline \multicolumn{6}{|l|}{ Education/Wykształcenie: } \\
\hline vocational/zawodowe & 15.6 & 9.4 & 25 & 50 & 0 \\
\hline secondary/średnie & 8 & 23.9 & 20.5 & 39.8 & 8 \\
\hline higher/wyższe & 6 & 24.1 & 18.1 & 44.6 & 7.2 \\
\hline \multicolumn{6}{|c|}{$\begin{array}{l}\text { Body weight according to BMI/ } \\
\text { Masa ciała wg BMI: }\end{array}$} \\
\hline underweight/niedowaga & 22.2 & 44.4 & 11.1 & 22.2 & 0 \\
\hline normal/prawidłowa & 4.3 & 21.7 & 27 & 43.5 & 3.5 \\
\hline overweight/nadwaga & 11.4 & 15.7 & 11.4 & 48.6 & 12.9 \\
\hline Total/Lącznie & 8.4 & 21.7 & 20.2 & 43.3 & 6.4 \\
\hline
\end{tabular}

Table II. Consumption frequency of light dairy products by age, education and body weight of respondents

Tabela II. Częstość spożycia produktów mlecznych typu light z uwzględnieniem wieku, wykształcenia i masy ciała badanych konsumentów

\begin{tabular}{|c|c|c|c|c|c|}
\hline \multirow{2}{*}{ Feature/Cecha } & \multicolumn{5}{|c|}{$\begin{array}{l}\text { Consumption frequency of light dairy products indicated by respondents (\%)/ } \\
\text { Częstość spożycia produktów mlecznych typu light wskazana przez badanych (\%) }\end{array}$} \\
\hline & $\begin{array}{c}\text { dailyl } \\
\text { codziennie }\end{array}$ & $\begin{array}{l}\text { several times a week/ } \\
\text { kilka razy w tygodniu }\end{array}$ & $\begin{array}{l}\text { several times a month/ } \\
\text { kilka razy w miesiącu }\end{array}$ & $\begin{array}{l}\text { rarelyl } \\
\text { rzadko }\end{array}$ & $\begin{array}{l}\text { i don't consume/ } \\
\text { nie spożywam }\end{array}$ \\
\hline \multicolumn{6}{|l|}{ Age/Wiek: } \\
\hline $19-30$ years/lat & 9.2 & 21.7 & 23.3 & 38.3 & 7.5 \\
\hline$>30$ years/lat & 8.4 & 25.3 & 14.5 & 43.4 & 8.4 \\
\hline \multicolumn{6}{|l|}{ Education/Wykształcenie: } \\
\hline vocational/zawodowe & 15.6 & 18.8 & 28.1 & 28.1 & 9.4 \\
\hline secondary/średnie & 8.0 & 29.5 & 14.8 & 38.6 & 9.1 \\
\hline higher/wyższe & 7.7 & 18.1 & 21.7 & 47.0 & 6.0 \\
\hline \multicolumn{6}{|c|}{$\begin{array}{l}\text { Body weight according to BMI/ } \\
\text { Masa ciała wg BMl: }\end{array}$} \\
\hline underweight/niedowaga & 16.7 & 33.3 & 11.1 & 33.3 & 5.6 \\
\hline normal/prawidłowa & 7.8 & 20.9 & 20.9 & 42.6 & 7.8 \\
\hline overweight/nadwaga & 8.6 & 24.3 & 20.0 & 38.6 & 8.6 \\
\hline Total/Łacznie & 8.9 & 23.2 & 19.7 & 40.4 & 7.9 \\
\hline
\end{tabular}

Table III. Consumption frequency of light-type fat products by age, education and body weight of respondents

Tabela III. Częstość spożycia produktów tłuszczowych typu light z uwzględnieniem wieku, wykształcenia i masy ciała badanych konsumentów

\begin{tabular}{|c|c|c|c|c|c|}
\hline \multirow{2}{*}{ Cecha } & \multicolumn{5}{|c|}{$\begin{array}{l}\text { Consumption frequency of light-type fat products indicated by respondents (\%)/ } \\
\text { Częstość spożycia produktów tłuszczowych typu light wskazana przez badanych (\%) }\end{array}$} \\
\hline & $\begin{array}{c}\text { dailyl } \\
\text { codziennie }\end{array}$ & $\begin{array}{l}\text { several times a week/ } \\
\text { kilka razy w tygodniu }\end{array}$ & $\begin{array}{l}\text { several times a month/ } \\
\text { kilka razy w miesiącu }\end{array}$ & $\begin{array}{l}\text { rarelyl } \\
\text { rzadko }\end{array}$ & $\begin{array}{l}\text { i don't consume } \\
\text { nie spożywam }\end{array}$ \\
\hline \multicolumn{6}{|l|}{ Age/Wiek: } \\
\hline $19-30$ years/lat & 0.8 & 6.7 & 11.7 & 35.8 & 45.0 \\
\hline$>30$ years/lat & 3.6 & 7.2 & 8.4 & 32.5 & 48.2 \\
\hline \multicolumn{6}{|l|}{ Education/Wykształcenie: } \\
\hline vocational/zawodowe & 3.1 & 12.5 & 18.8 & 21.9 & 43.8 \\
\hline secondary/średnie & 3.4 & 9.1 & 8.0 & 38.6 & 40.9 \\
\hline higher/wyższe & 2.4 & 0 & 9.7 & 34.9 & 53.0 \\
\hline \multicolumn{6}{|c|}{$\begin{array}{l}\text { Body weight according to BMI / } \\
\text { Masa ciała wg BMI: }\end{array}$} \\
\hline underweight/niedowaga & 0 & 22.2 & 16.7 & 16.7 & 44.4 \\
\hline normal/prawidłowa & 1.7 & 3.5 & 11.3 & 38.3 & 45.2 \\
\hline overweight/nadwaga & 2.9 & 8.6 & 7.1 & 32.9 & 48.6 \\
\hline Total/Łącznie & 2.0 & 6.9 & 10.3 & 34.5 & 46.3 \\
\hline
\end{tabular}


Table IV. Consumption frequency of light sweets by age, education and body weight of respondents Tabela IV. Częstość spożycia słodyczy typu light z uwzględnieniem wieku, wykształcenia i masy ciała badanych konsumentów

\begin{tabular}{|c|c|c|c|c|c|}
\hline \multirow{2}{*}{ Features/Cecha } & \multicolumn{5}{|c|}{$\begin{array}{l}\text { Consumption frequency of light sweets indicated by respondents (\%)/ } \\
\text { Częstość spożycia słodyczy typu light wskazana przez badanych (\%) }\end{array}$} \\
\hline & $\begin{array}{c}\text { dailyl } \\
\text { codziennie }\end{array}$ & $\begin{array}{l}\text { several times a week/ } \\
\text { kilka razy w tygodniu }\end{array}$ & $\begin{array}{l}\text { several times a month/ } \\
\text { kilka razy w miesiącu }\end{array}$ & $\begin{array}{l}\text { rarelyl } \\
\text { rzadko }\end{array}$ & $\begin{array}{l}\text { i don't consume/ } \\
\text { nie spożywam }\end{array}$ \\
\hline \multicolumn{6}{|l|}{ Age/Wiek: } \\
\hline 19-30 years/lat & 0.8 & 5.0 & 10.0 & 33.3 & 50.8 \\
\hline$>30$ years/lat & 1.2 & 9.6 & 3.6 & 25.3 & 60.2 \\
\hline \multicolumn{6}{|l|}{ Education/Wykształcenie: } \\
\hline vocational/zawodowe & 3.1 & 6.3 & 21.9 & 34.4 & 34.4 \\
\hline secondary/średnie & 1.1 & 10.2 & 4.5 & 31.8 & 52.3 \\
\hline higher/wyższe & 3.6 & 4.8 & 4.8 & 26.5 & 65.1 \\
\hline \multicolumn{6}{|c|}{$\begin{array}{l}\text { Body weight according to BMI/ } \\
\text { Masa ciała wg BMI: }\end{array}$} \\
\hline underweight/niedowaga & 0 & 5.6 & 11.1 & 33.3 & 50.0 \\
\hline normal/prawidłowa & 0.9 & 5.2 & 7.8 & 29.6 & 56.5 \\
\hline overweight/nadwaga & 1.4 & 10.0 & 5.7 & 30.0 & 52.9 \\
\hline Total/Łącznie & 1.0 & 6.9 & 7.4 & 30.0 & 54.7 \\
\hline
\end{tabular}

Table V. Consumption frequency of light drinks by age, education and body weight of respondents Tabela V. Częstość spożycia napojów typu light z uwzględnieniem wieku, wykształcenia i masy ciała badanych konsumentów

\begin{tabular}{|c|c|c|c|c|c|}
\hline \multirow{2}{*}{ Cecha } & \multicolumn{5}{|c|}{$\begin{array}{l}\text { Consumption frequency of light drinks indicated by respondents (\%)/ } \\
\text { Częstość spożycia napojów typu light wskazana przez badanych }(\%)\end{array}$} \\
\hline & $\begin{array}{l}\text { dailyl } \\
\text { codziennie }\end{array}$ & $\begin{array}{l}\text { several times a week/ } \\
\text { kilka razy w tygodniu }\end{array}$ & $\begin{array}{l}\text { several times a month/kilka } \\
\text { razy w miesiącu }\end{array}$ & $\begin{array}{l}\text { rarelyl } \\
\text { rzadko }\end{array}$ & $\begin{array}{l}\text { i don't consumel } \\
\text { nie spożywam }\end{array}$ \\
\hline \multicolumn{6}{|l|}{ Age/Wiek: } \\
\hline 19-30 years/lat & 3.3 & 10.8 & 26.7 & 33.3 & 25.8 \\
\hline$>30$ years/lat & 2.4 & 8.4 & 12.0 & 50.6 & 26.5 \\
\hline \multicolumn{6}{|l|}{ Education/Wykształcenie: } \\
\hline vocational/zawodowe & 12.5 & 12.5 & 28.1 & 25.0 & 21.9 \\
\hline secondary/średnie & 2.3 & 11.4 & 19.3 & 40.9 & 26.1 \\
\hline higher/wyższe & 0 & 7.2 & 19.3 & 45.8 & 27.7 \\
\hline \multicolumn{6}{|c|}{$\begin{array}{l}\text { Body weight according to BMI/ } \\
\text { Masa ciała wg BMI: }\end{array}$} \\
\hline underweight/niedowaga & 0 & 11.1 & 22.2 & 27.8 & 38.9 \\
\hline normal/prawidłowa & 2.6 & 10.4 & 20.0 & 40.0 & 26.1 \\
\hline overweight/nadwaga & 4.3 & 8.6 & 20.0 & 44.3 & 22.9 \\
\hline Total/tącznie & 3.0 & 9.9 & 20.7 & 40.4 & 26.1 \\
\hline
\end{tabular}

Statistical analysis revealed a correlation $(\mathrm{p}<0.05)$ between the consumption frequency of light drinks and: - age ( $\mathrm{r}=-0.17$; weak correlation),

- educational level $(r=-0.19$; weak correlation)

- body weight of respondents $(r=-0.06$; weak correlation).

The motives for reaching for light foods and drinks, which were most often mentioned by respondents, were the encouraging effect of advertising (40.4\% of respondents) and willingness to take care of a healthy/ slim body (33.5\% of respondents). Other motives include encouragement to consume light foods and drinks by family/friends ( $12.8 \%$ of respondents) or doctor/dietitian (3.9\% of respondents) and others, among which curiosity and lower energy content were most often mentioned ( $9.4 \%$ of respondents) (Fig. 1). powyżej 30 r.ż. niż w przedziale wiekowym 19-30 lat, z wykształceniem wyższym niż zawodowym lub średnim oraz z nadwagą niż z prawidłową masą ciała i niedowagą. W grupie osób z niedowagą najwyższy odsetek stanowili konsumenci, którzy nie spożywają napojów typu light (tab. V).

Analiza statystyczna wskazała na występowanie korelacji $(\mathrm{p}<0,05)$ pomiędzy częstością spożycia napojów typu light oraz:

- wiekiem $(r=-0,17$; korelacja słaba),

- poziomem wykształcenia $(\mathrm{r}=-0,19$; korelacja słaba),

- masą ciała badanych konsumentów ( $\mathrm{r}=0,06$; korelacja słaba).

Wśród motywów sięgania po produkty typu light, które badani konsumenci wymieniali najczęściej, wskazywano na zachęcające działanie reklamy (40,4\% badanych) 


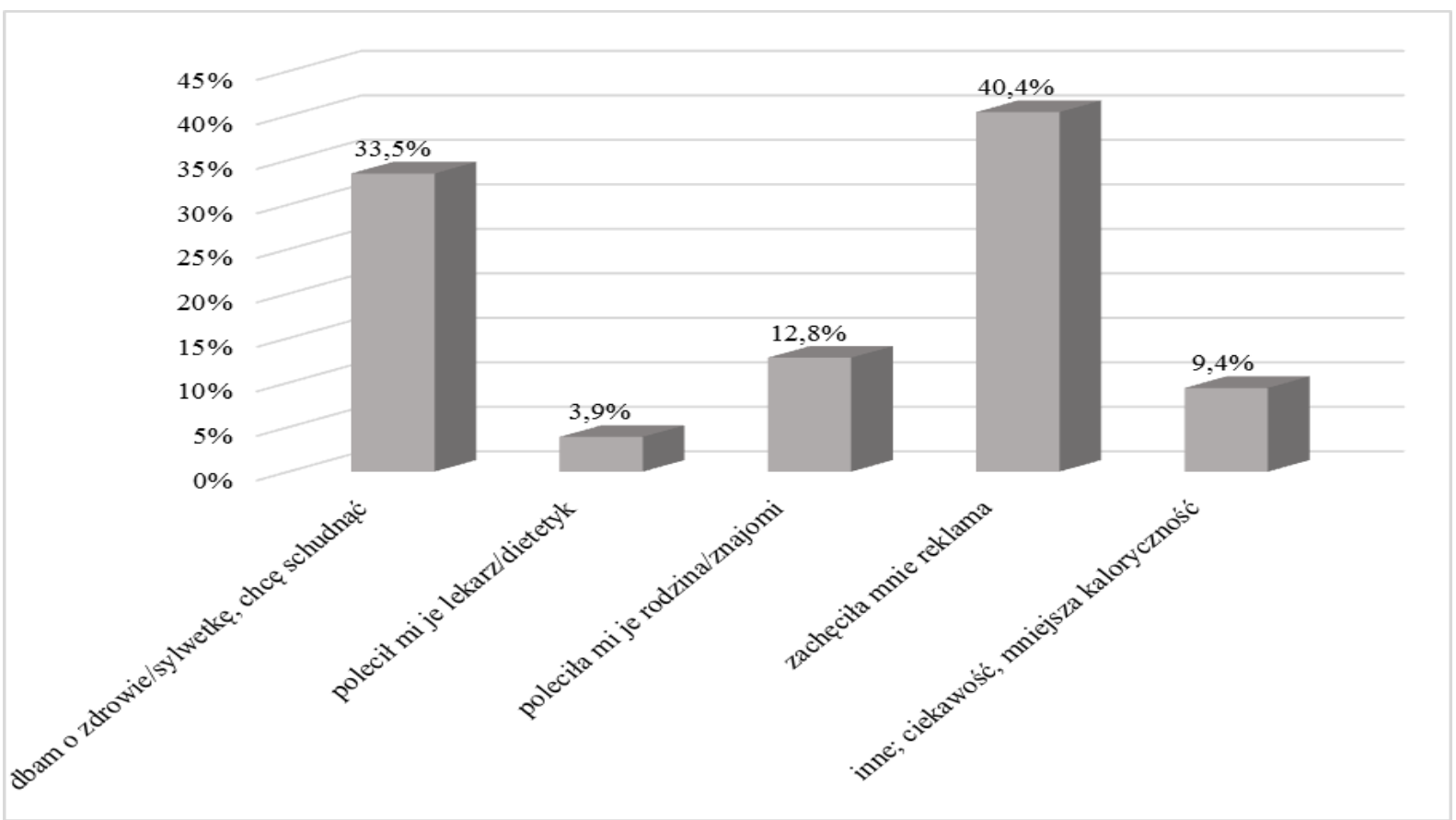

Fig. 1. Motives for which respondents choose light products.

Ryc. 1. Motywy, z powodu których badani konsumenci sięgają po produkty typu light.

\section{DISCUSSION}

In spite of the increasing production and assortment of light foods and drinks, often identified with low energy density foods, both the results of the author's own research and those of other authors [6,7] indicate a low interest in products from this group.

The analysis of the results of the author's own research has revealed that dairy products are the most frequently consumed light foods. Similar results were obtained by Wierzbicka et al., who evaluated the consumption of low-energy foods by 130 women with a BMI above 25. As their results demonstrated, milk, yoghurt and cheese were the most frequently consumed light foods, eaten by $42 \%, 35 \%$ and $28 \%$ of the surveyed women respectively [8]. Similar conclusions were also drawn by Flaczyk et al., who found that yoghurts were the most frequently consumed light foods [9], and Całyniuk et al., who stated that the most often consumed light foods by Silesian voivodeship residents were dairy products [6]. Also the results of the study conducted by Babicz-Zielińska, who assessed consumer attitudes towards novel foods, indicate the high consumption of low-fat dairy products [10]. Similar results were also obtained by Zandstra et al., who measured the impact of health and taste preferences on the consumption of foods with reduced and increased fat content among 132 adults in the Netherlands. The authors of the study indicated a great interest in light dairy products and related higher consumption than products with a regular fat content [11]. Summing up the performed analyses, it may be assumed that the reason for the frequent choice of light oraz chęć dbania o zdrowie/sylwetkę $(33,5 \%$ badanych). Pozostałe motywy to zachęcenie do ich spożywania przez rodzinę/znajomych (12,8\% badanych) lub lekarza/dietetyka (3,9\% badanych) oraz inne, wśród których wymieniano najczęściej ciekawość i mniejszą wartość energetyczną ( $9,4 \%$ badanych) (ryc. 1).

\section{DYSKUSJA}

Mimo rosnącej produkcji i zwiększenia asortymentu żywności typu light, utożsamianej często z żywnością o obniżonej wartości energetycznej, zarówno wyniki badań własnych, jak i innych autorów [6,7] wskazują na niewielkie zainteresowanie nimi.

Analiza wyników badań własnych wykazała, iż najczęściej spożywanymi produktami typu light są produkty mleczne. Podobne wyniki otrzymali Wierzbicka i wsp., którzy oceniali ich konsumpcję przez 130 kobiet z BMI powyżej 25. Jak pokazały ich wyniki, do najczęściej spożywanych przez nie produktów typu light należały mleko (42\%), jogurty (35\%) i sery (28\%) [8]. Do podobnych wniosków doszli również Flaczyk i wsp., którzy wykazali, że najczęściej konsumowanymi przez badanych studentów produktami typu light były jogurty [9], oraz Całyniuk i wsp, którzy stwierdzili najczęstsze spożycie wśród mieszkańców województwa śląskiego produktów mlecznych [6]. Również wyniki badania Babicz-Zielińskiej, która oceniała postawy konsumentów wobec nowej żywności, wskazują na wysokie spożycie produktów mlecznych niskotłuszczowych [10]. Podobne wyniki otrzymali także Zandstra i wsp., oceniający wpływ stanu zdrowia i preferencji 
dairy products may be their high availability. The more frequent preference for low-fat dairy products may also be associated with the fact that many scientific studies indicate a reduced risk of cardiovascular diseases when consuming dairy products with a lower fat content $[12,13]$.

According to the study by Całyniuk et al., light sweets and snacks are consumed by $17.3 \%$ of respondents [6], in the author's own research the total percentage is $45.3 \%$, with these products more often used by respondents between 19 and 30 years of age, with vocational education, and rarely by people over 30 , with higher education. Different results were obtained by Jeżewska-Zychowicz et al., whose study was aimed, among others, at assessing the interest of respondents in sweets with special health properties. In the authors' opinion, light sweets were more frequently consumed by respondents up to the age of 44 , and rarely by people with vocational and primary education [14].

The data obtained as a result of analysis of the author's own research indicate that the main motive for choosing light foods and drinks was advertising (40.4\% of responses) and willingness to take care of a healthy/ slim body (33.5\% of responses). Similar results were obtained by Kubiak et al., according to which $48 \%$ of respondents indicated that food products are the goods most often chosen under the influence of advertising [15]. Slightly different results were obtained by Fortuna et al. because the first group (diabetics), when choosing light waffles, was guided mainly by health reasons (about 55\%), whereas the second group (healthy, young people) consumed light waffles under the influence of friends or out of curiosity, $35 \%$ and $40 \%$ of respondents respectively [16]. In the study by Szczepańska et al., who evaluated the factors determining the choice of instant products by 395 university students, it was found that in the case of this group of products, advertising was the factor most often identified by the respondents as irrelevant [17]. Similarly, a study by Dąbrowska et al., whose aim was to determine the level of knowledge of new generation foods as well as behaviours in relation to these products among 210 randomly selected people of both sexes, revealed that $31 \%$ of respondents indicated health related aspects, while $18.1 \%$ pointed to sensory qualities. Among those who indicated health related aspects, $38.7 \%$ had higher education [18].

In addition to the obvious advantages of consuming functional food, and thus also low energy density foods, another aspect should be considered. Functional foods are often confused or identified with light foods and drinks and products described by manufacturers using the substitute of the term "light". Although the consumption of light foods and drinks is not high, as indicated by our own research and the research of the aforementioned authors, taking into account the fact that potential consumers may not be only healthy people, but also obese or diabetic persons, it should be stated that it is necessary to conduct broadly understood individual and group nutrition education related to the presence of this type of food on the market. smakowych na konsumpcję żywności z obniżoną i podwyższoną zawartością tłuszczu wśród 132 dorosłych osób w Holandii. Autorzy badania wykazali duże zainteresowanie produktami mlecznymi typu light i ich większe spożycie, niż produktów z tradycyjną ilością tłuszczu [11]. Podsumowując dokonane analizy, można domniemywać, iż przyczyną częstszego wybierania produktów mlecznych typu light może być ich duża dostępność, a także fakt, iż wiele badań naukowych wskazuje na zmniejszenie ryzyka zachorowalności na choroby sercowo-naczyniowe dzięki ich spożywaniu [12,13]. Według badania Całyniuk i wsp. słodycze oraz przekąski typu light spożywa 17,3\% badanych osób [6]; w badaniach własnych odsetek ten wynosi łacznie $45,3 \%$, przy czym po produkty te częściej sięgali badani między 19 a 30 rokiem życia z wykształceniem zawodowym, a najrzadziej osoby po 30 r.ż. z wykształceniem wyższym. Odmienne wyniki otrzymali Jeżewska-Zychowicz i wsp., którzy za cel badań przyjęli m.in. ocene zainteresowania badanych słodyczami ze specjalnymi właściwościami zdrowotnymi. W opinii autorów po słodycze typu light częściej sięgali badani do 44 r.ż., a najrzadziej osoby z wykształceniem zawodowym i podstawowym [14].

Dane uzyskane w wyniku analizy badań własnych wskazują, że głównym motywem sięgania po produkty typu light były reklama (40,4\% odpowiedzi) oraz chęć dbania o zdrowie/sylwetkę (33,5\% odpowiedzi). Podobne wyniki otrzymali Kubiak i wsp. Spośród badanych przez nich osób - 48\% wskazało, że produktami najczęściej wybieranymi pod wpływem reklamy są artykuły spożywcze [15]. Nieco odmienne wyniki otrzymali Fortuna i wsp., gdyż w pierwszej z badanych przez nich grup (osoby chore na cukrzycę), wybierając wafle typu light, kierowano się głównie względami zdrowotnymi (ok. 55\%), natomiast w drugiej grupie (zdrowe, młode osoby) spożywano wafle typu light pod wpływem zachęty znajomych lub z ciekawości, odpowiednio 35\% i 40\% badanych [16]. W badaniach Szczepańskiej i wsp., oceniając czynniki determinujące wybór produktów typu instant przez 395 studentów uczelni wyższych, wykazano, iż w przypadku tej grupy produktów czynnikiem najczęściej uznawanym za bez znaczenia była reklama [17]. Podobnie w badaniu Dąbrowskiej i wsp., którego celem było określenie stopnia znajomości żywności nowej generacji oraz zachowań w odniesieniu do tych produktów wśród 210 losowo wybranych osób obojga płci, wykazano, iż 31\% badanych wskazało na względy zdrowotne, natomiast $18,1 \%$ na walory sensoryczne. Spośród osób, które wskazały aspekty zdrowotne, $38,7 \%$ legitymowało się wykształceniem wyższym [18].

Oprócz niewątpliwych zalet wynikających ze spożywania żywności funkcjonalnej, a co za tym idzie również produktów o obniżonej wartości energetycznej, należy zwrócić uwagę na inny aspekt. Żywność funkcjonalna często jest mylona bądź też utożsamiana z żywnością typu light i produktami opisywanymi przez producentów przy użyciu synonimu określenia light. Choć spożycie produktów typu light nie jest wysokie, na co 


\section{CONCLUSIONS}

1. Among adult respondents, the consumption of fast food is rare, and the most frequently indicated motive for its consumption is encouragement by advertising and care for a healthy/slim body.

2. There was a weak or low correlation between the consumption frequency of light foods and age, education and body weight of the respondents.

3. It seems necessary to provide nutrition education from an early age, especially among children and adolescents, and to continue it with adults.

\section{Author's contribution}

Study design - E. Szczepańska

Data collection - E. Grudowska

Data interpretation - E. Szczepańska

Statistical analysis - E. Szczepańska, E. Grudowska

Manuscript preparation - E. Szczepańska, E. Grudowska

Literature research - E. Szczepańska, E. Grudowska wskazują badania własne oraz cytowanych wcześniej autorów, oraz zważywszy na fakt, iż potencjalnymi jej konsumentami mogą być nie tylko ludzie zdrowi, lecz także osoby otyłe czy chorujące na cukrzycę, należy stwierdzić, iż konieczne jest prowadzenie szeroko rozumianej edukacji żywieniowej indywidualnej oraz grupowej, związanej z obecnością na rynku tego typu żywności.

\section{WNIOSKI}

1. Wśród ankietowanych osób dorosłych spożycie żywności typu light jest rzadkie, przy czym najczęściej wskazywanym motywem jej spożywania jest zachęcenie przez reklamę oraz dbałość o zdrowie/sylwetkę.

2. Stwierdzono występowanie słabej lub niskiej korelacji pomiędzy częstością spożycia żywności typu light oraz wiekiem, wykształceniem i masa ciała badanych osób.

3. Konieczne wydaje się prowadzenie edukacji żywieniowej od najmłodszych lat, szczególnie wśród dzieci i młodzieży, oraz kontynuowanie jej wśród osób dorosłych.

\section{REFERENCES}

1. Świderski F., Kolanowski W. Żywność funkcjonalna i dietetyczna. W Żywność wygodna i żywność funkcjonalna. Red. F. Świderski. Wydawnictwo Naukowo-Techniczne. Warszawa 2003: 27-31.

2. Diet, nutrition and the prevention of chronic diseases: report of a joint WHO/ FAO expert consultation. WHO Technical Report Series 916, Geneva 2003

3. Grajeta H. Żywność funkcjonalna w profilaktyce chorób układu krążenia Adv. Clin. Exp. Med. 2004; 13(3): 503-510.

4. Saluk-Juszczak J., Kołodziejczyk J., Babicz K., Królewska K. Żywność funkcjonalna - rola nutraceutyków w profilaktyce chorób układu krążenia Kosmos - problemy nauk biologicznych 2010; 59(3-4): 527-538.

5. Rozporządzenie Parlamentu Europejskiego i Rady nr 1333/2008 z dnia 16 grudnia 2008 roku w sprawie dodatków do żywności, https://eur-lex.europa.eu/ legal-content/PL/TXT/?uri=CELEX:32008R1333 [dostęp: 11.05.2016] 6. Całyniuk B., Preidl K., Szczepańska E., Białek-Dratwa A., Jędrzejowska K. Grochowska-Niedworok E. Czestotliwość spożycia produktów typu light przez mieszkańców województwa śląskiego z uwzględnieniem wieku, wykształcenia i BMI. W: Zdrowy styl życia: bezpieczeństwo żywności i zdrowe żywienie. Red. L.T. Niebrój, E. Grochowska-Niedworok, M. Kardas. Raleigh: Lulu Enterprises, Inc. USA 2015: 59-66.

7. Jeżewska-Zychowicz M., Jeznach M., Kosicka-Gębska M. Gotowość konsumentów do spożywania żywności typu light. Bromat. Chem. Toksykol. 2012 45(3): 603-607.

8. Wierzbicka E., Kochańska A. Spożycie produktów o obniżonej wartości energetycznej w wybranej grupie kobiet. Żyw. Człow. Met. 2007; 34(1-2): 204-208.

9. Flaczyk E., Kobus J., Korczak J. Assessme nt of consumption of "light" food by students. Acta Sci. Pol. Technol. Aliment. 2006; 5(1): 173-181.

10. Babicz-Zielińska E. Postawy konsumentów wobec nowej żywności. Zeszyty Naukowe Akademii Morskiej w Gdyni 2010; 65: 16-22.

11. Zandstra E., de Graaf C., Van Staveren W. Influence of health and taste attitudes on consumption of low - and high - fat foods. Food Quality and Preference 2001; 12(1): 75-82, doi: 10.1016/S0950-3293(00)00032-X.

12. Gopinath B., Flood V.M., Wang J.J., Barlutsky G., Mitchell P. Lower dairy products and calcium intake is associated with adverse retinal vascular changes in older adults. Nutr. Metab. Cardiovasc. Dis. 2014; 24(2): 155-161, doi: 10.1016/j.numecd.2013.06.009.

13. Toledo E., Delgado-Rodriguez M., Estruch R., Salas-Salvado J., Corella D., Gomez-Gracia E., Fiol M., Lamuela-Raventós R.M., Schröder H., Arós F., Ros E., Ruíz-Gutiérrez V., Lapetra J., Conde-Herrera M., Sáez G., Vinyoles E., Martínez-González M.A. Low-fat dairy products and blood pressure: follow-up of 2290 older persons at high cardiovascular risk participating in the PREDIMED study. Br. J. Nutr. 2009; 101(1): 59-67, doi: 10.1017/ S0007114508981496

14. Jeżewska-Zychowicz M., Jeznach M., Kosicka-Gębska M. Funkcjonalność słodyczy w opinii konsumentów. Bromat. Chem. Toksykol. 2011;44(3):993-998. 15. Kubiak A., Kuleczka-Raszewska M. Wpływ reklamy na wybory zdrowotne Polaków. Med. Ogólna i Nauki o Zdrowiu 2014, 20(1): 26-30.

16. Fortuna T., Stachura M., Buda A. Właściwości fizykochemiczne i ocena sensoryczna wafli typu light. Technologia Alimentaria 2003; 2(1): 83-96.

17. Szczepańska E., Janion K., Szeja N., Stanuch B. Czynniki decydujące o wyborze produktów typu instant na przykładzie studentów uczelni wyższych. W: M. Choroby XXI wieku: wybrane zagadnienia. Fundacja na rzecz promocji nauki i rozwoju TYGIEL. Red. Olszówka, K. Maciąg. Lublin 2015: 104-117.

18. Dąbrowska A., Babicz-Zielińska E. Zachowania konsumentów w stosunku do żywności nowej generacji. Hygeia Public Health 2011; 46(1): 39-46. 